\title{
Prolonged Expression of Secreted Enzymes in Dogs After Liver-Directed Delivery of Sleeping Beauty Transposons: Implications for Non-Viral Gene Therapy of Systemic Disease
}

\author{
Elena L. Aronovich, ${ }^{1, *}$ Kendra A. Hyland, Bryan C. Hall, Jason B. Bell,, Erik R. Olson, \\ Myra Urness Rusten, ${ }^{3}$ David W. Hunter, ${ }^{3}$ N. Matthew Ellinwood, ${ }^{4}$ R. Scott Mclvor, ${ }^{1,2}$ \\ and Perry B. Hackett ${ }^{1,2}$
}

${ }^{1}$ Department of Genetics, Cell Biology and Development and Center for Genome Engineering and ${ }^{3}$ Department of Radiology, University of Minnesota, Minneapolis, Minnesota; ${ }^{2}$ Discovery Genomics, Inc., Minneapolis, Minnesota; ${ }^{4}$ Department of Animal Science, lowa State University, Ames, lowa.

The non-viral, integrating Sleeping Beauty (SB) transposon system is efficient in treating systemic monogenic disease in mice, including hemophilia $\mathrm{A}$ and $\mathrm{B}$ caused by deficiency of blood clotting factors and mucopolysaccharidosis types I and VII caused by $\alpha$-L-iduronidase (IDUA) and $\beta$-glucuronidase (GUSB) deficiency, respectively. Modified approaches of the hydrodynamics-based procedure to deliver transposons to the liver in dogs were recently reported. Using the transgenic canine reporter secreted alkaline phosphatase (cSEAP), transgenic protein in the plasma was demonstrated for up to 6 weeks post infusion. This study reports that immunosuppression of dogs with gadolinium chloride $\left(\mathrm{GdCl}_{3}\right)$ prolonged the presence of cSEAP in the circulation up to 5.5 months after a single vector infusion. Transgene expression declined gradually but appeared to stabilize after about 2 months at approximately fourfold baseline level. Durability of transgenic protein expression in the plasma was inversely associated with transient increase of liver enzymes alanine transaminase and aspartate transaminase in response to the plasmid delivery procedure, which suggests a deleterious effect of hepatocellular toxicity on transgene expression. $\mathrm{GdCl}_{3}$ treatment was ineffective for repeat vector infusions. In parallel studies, dogs were infused with potentially therapeutic transposons. Activities of transgenic IDUA and GUSB in plasma peaked at 50-350\% of wildtype, but in the absence of immunosuppression lasted only a few days. Transposition was detectable by excision assay only when the most efficient transposase, SB100X, was used. Dogs infused with transposons encoding canine clotting factor IX $(c F I X)$ were treated with $\mathrm{GdCl}_{3}$ and showed expression profiles similar to those in $c S E A P$-infused dogs, with expression peaking at $40 \% \mathrm{wt}(2 \mu \mathrm{g} / \mathrm{mL})$. It is concluded that $\mathrm{GdCl}_{3}$ can support extended transgene expression after hydrodynamic introduction of SB transposons in dogs, but that alternative regimens will be required to achieve therapeutic levels of transgene products.

Keywords: monogenic disease, mucopolysaccharidosis, hemophilia, immune response, hydrodynamicsbased delivery

\section{INTRODUCTION}

NON-VIRAL GENE THERAPY vectors are undergoing evaluation in human gene therapy clinical trials due to simplicity of construction and customizing to individual needs of patients, a long shelf life, and lower costs of mass production compared to viral gene therapy vectors. ${ }^{1-3}$ The major obstacle to using non-viral vectors in vivo is delivery to target cells because naked DNA is unable to penetrate cellular and nuclear barriers. ${ }^{4}$ However, introduction of the hydrodynamics-based procedure, an effective method of systemic tail-vein delivery of plasmids to rodents, gave a powerful impulse to preclinical studies using non-viral vectors. ${ }^{5,6}$ Fol-

${ }^{*}$ Correspondence: Dr. Elena L. Aronovich, Department of Genetics, Cell Biology and Development, 6-160 Jackson Hall, 321 Church Street, University of Minnesota, Minneapolis, MN 55455.E-mail: arono001@umn.edu

(c) Elena L. Aronovich et al. 2017; Published by Mary Ann Liebert, Inc. This article is available under the Creative Commons License CC-BY-NC (http://creativecommons.org/licenses/by-nc/4.0). This license permits non-commercial use, distribution and reproduction in any medium, provided the original work is properly cited. Permission only needs to be obtained for commercial use and can be done via RightsLink. 
lowing infusion, expression of injected DNA is almost entirely (99\%) in the liver, which becomes a depot for expression of therapeutic proteins. In case of secreted transgenic proteins, they can be released in large amounts by liver cells into the circulation to be distributed into untransduced cells throughout the body.

The Sleeping Beauty (SB) transposon system is a non-viral vector that can mediate stable integration of therapeutic transgenes into the genomes of treated animal cells ${ }^{7-10}$ and provides sustained expression up to an entire lifetime. ${ }^{11-13}$ Importantly, a nearly random integration profile makes this vector safer than its viral counterparts. ${ }^{1,2,4,10,14}$ The SB transposon system has proved effective in mouse models of several monogenic diseases, including hemophilia $\mathrm{A}^{15}$ and $\mathrm{B}^{11,16,17}$ and mucopolysaccharidoses (MPS) types I and VII. ${ }^{18,19}$ Clotting factor IX $(F I X)$, in particular, has been a transgene of choice in many gene therapy studies due to its low immunogenicity. In addition, a low concentration of FIX in the blood is needed to attain therapeutic efficacy, and the relatively small size of its coding sequence permits easy subcloning into a variety of therapeutic expression cassettes. ${ }^{20}$ The current standard of care for hemophilia B is lifelong FIX replacement therapy to maintain the circulating levels at above $1 \%$ of normal. This treatment prevents hemorrhages but is not curative. ${ }^{21}$ MPS I and MPS VII are progressive lysosomal storage disorders caused by deficiency of lysosomal enzymes $\alpha$-L-iduronidase (IDUA; EC 3.2.1.76) and $\beta$-glucuronidase (GUSB; EC 3.2.1.31), respectively. The current standard of care for MPS I is bone-marrow transplantation and/ or enzyme replacement therapy, ${ }^{22}$ and while MPS VII is extremely rare in humans (1:250,000), its animal models are useful for testing novel therapies due to the availability of assays for quantifying and localizing GUSB activity. ${ }^{23}$ Preclinical studies using SB transposons in MPS I mice have demonstrated lifelong IDUA expression in the liver at about 100fold wild type (WT), which results in therapeutic effects comparable to those attained with retroviral liver-directed gene therapy. ${ }^{13,19}$ However, mouse data are insufficient for translation to human clinical trials due to many differences, including organ size, metabolism, and life-span. ${ }^{24}$

Dog models exist for both MPS I ${ }^{25,26}$ and MPS VII. ${ }^{27,28}$ These animals have been used as translational models for preclinical studies with gammaretroviral and adeno-associated viral vectors. ${ }^{29-36}$ Amelioration of the disease has been achieved with liver-directed gamma retroviral gene therapy of neonatal dogs. ${ }^{36}$ However, intravenous (i.v.) injection of gamma-retroviral vectors into adult animals was ineffective, even in mice, unless immune responses were blocked. ${ }^{37}$ Immune responses can override achievements of gene therapy by eliminating either the transgenic protein activity or the transduced cells. ${ }^{36-38}$ Construction of vectors with species-specific therapeutic transgenes and liverspecific promoters that restrict expression to hepatocytes have been shown to reduce, although not eliminate, deleterious immunological responses. ${ }^{38-40}$

In mice, success of hydrodynamics-based DNA delivery to the liver depends primarily on two parameters: volume and speed of infusion. The tail-vein injection is routinely performed with a syringe. In the dog, delivery of plasmids is accomplished by isolation of the liver using balloon catheters with infusion directly into the hepatic veins, which is a surgical procedure performed by an interventional team under radiologic guidance. The injection route, properties of the vasculature and of the target organ (the liver), as well as the direction of flow after hydrodynamics-based injection are important parameters that differ substantially between mice and large animals. ${ }^{4,41,42}$

Until recently, the efficacy of non-viral DNA delivery to treat large animals has been discouraging. ${ }^{4,42-44}$ The authors developed and examined the potential of catheter-mediated infusion via the hepatic veins wherein targeted liver tissues are isolated from the blood flow by balloon occlusion of blood vessels. In dogs aged $\geq 3$ months,${ }^{41}$ detectable expression of the reporter enzyme canine serum alkaline phosphatase (cSEAP) was achieved for up to 6 weeks, a duration that is too short for clinical application, which requires extended gene expression. Consequent delivery of therapeutic transposons carrying IDUA and GUSB reported here yielded a low albeit therapeutically relevant level of initial expression, but was measurable for only a few days.

It was hypothesized that with immune suppression, transgene expression attained by the delivery method would be prolonged and might be maintained at therapeutic levels for systemic diseases. Here, in $c S E A P$ - and $c F I X$-treated dogs, prolonged transgene expression after balloon catheter-mediated delivery is demonstrated for the first time, which lays the groundwork for further improvement of immunosuppression and transposition in large animal models.

\section{MATERIALS AND METHODS}

\section{Animals and infusions}

All animal procedures were reviewed and approved by the University of Minnesota Institu- 
tional Animal Care and Use Committee. C57BL/6 mice were obtained from Jackson Laboratories, maintained under specific-pathogen-free conditions, and provided food and water ad libitum. Male beagles were procured from a USDA class-A vendor for the described procedures. The MPS VII mixed breed dog was produced at the Department of Animal Science of Iowa State University. The dogs were fasted for $12 \mathrm{~h}$ prior to anesthesia, then sedated with acepromazine $0.4 \mathrm{mg} / \mathrm{kg} \mathrm{SQ}$ and atropine $0.05 \mathrm{mg} / \mathrm{kg} \mathrm{SQ}$ or torbugesic at $0.05-0.5 \mathrm{mg} / \mathrm{kg}$ SQ. Anesthesia was induced with propofol at $4 \mathrm{mg} /$ $\mathrm{kg}$ i.v. followed by intubation and general anesthesia using isoflurane $1-2 \%$ with $3-4 \mathrm{~L} / \mathrm{min}$ of oxygen at approximately $15 \mathrm{cc} / \mathrm{kg}$ tidal volume. Animals were continuously monitored throughout the procedure by visual assessment, electrocardiogram, and intravascular venous pressure recording.

Two different strategies were used for balloonmediated occlusion of the liver with subsequent infusion of DNA into the hepatic venous circulation. The double-balloon system of Hyland et al. ${ }^{41 \text { (Fig. 1A) }}$ was applied in Dog9-1 and Dog13. A custom double-balloon catheter with infusion ports was introduced through the right femoral vein into the inferior vena cava, and a second pressuresensing catheter was introduced through the left femoral vein, with the end of the catheter positioned between the two balloons. This procedure delivered therapeutic plasmids to both right and

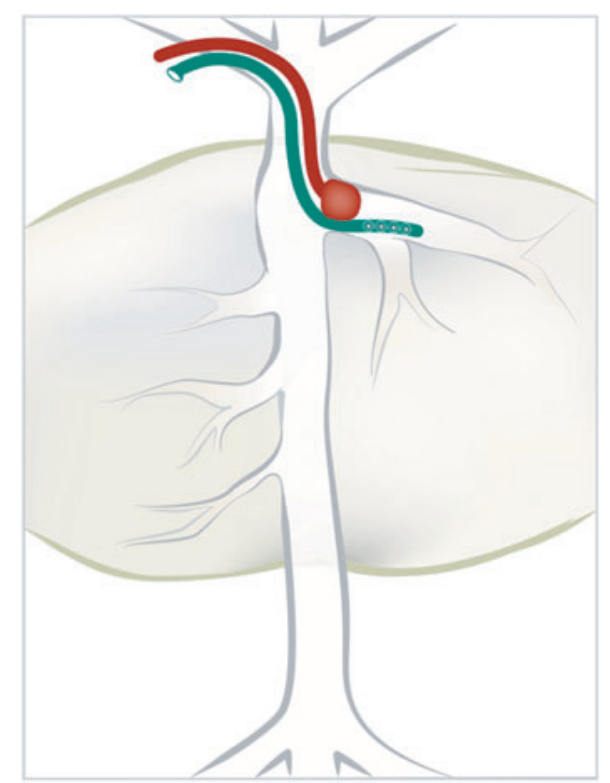

Figure 1. Single-balloon strategy used for infusion of DNA into the left side of the liver through the left hepatic vein in all dogs listed in Table 1 except Dogs 9-1 and 13. The single-balloon catheter is indicated in red while the catheter for DNA delivery is shown in teal. An additional catheter introduced to monitor intravascular pressure is not shown. left lobes of the liver. ${ }^{41}$ The single-balloon system (Fig. 1) was used in all dog experiments except Dogs 9-1 and 13. This catheter was introduced through the right jugular vein to the inferior vena cava and positioned just inside the left hepatic vein for delivery to the left side of the liver. A second pressure-sensing catheter was introduced alongside the balloon catheter from the right jugular vein, with the end of the catheter positioned distal to the balloon. This procedure was designed to provide focused plasmid delivery to the left side of the liver.

The infusion parameters developed by Hyland et $a l .{ }^{41}$ served as guidelines: DNA concentration of $2 \mathrm{mg} / \mathrm{kg}$ in a total infusion solution volume of $200 \mathrm{~mL}$ was delivered in $10-20 \mathrm{~s}$ to achieve intravascular pressure peaks of $100-200 \mathrm{mmHg}$ (Table 1 ). The DNA dose in all but one dog was within a 1.5fold range of $2 \mathrm{mg} / \mathrm{kg}$, which Hyland et al. found to be nearly saturating. The MPS VII Dog28 received a triple dose of plasmid, as explained below.

\section{Immunomodulation}

Cyclophosphamide (CP; Sigma-Aldrich, St. Louis, MO) was administered i.v. at $10 \mathrm{mg} / \mathrm{kg} 1$ day before and then again immediately prior to plasmid injection and then once weekly for 30 days. $\mathrm{GdCl}_{3} \times 6 \mathrm{H}_{2} \mathrm{O}(10 \mathrm{mg} / \mathrm{kg}$; Sigma-Aldrich) was administered i.v. 1 day before and then immediately prior to plasmid injection and then twice weekly for 30 days. Dexamethasone (Dex) was injected at $1 \mathrm{mg} / \mathrm{kg}$ for 10 days, starting 1 day prior to plasmid infusion. Dogs receiving $\mathrm{GdCl}_{3}$ were implanted with a port to prevent damage of small veins and spare animals discomfort and pain due to multiple injections and blood draws.

\section{SB vectors}

Vectors used in this study are shown in Fig. 2. SB transposons for cSEAP expression and human (h)GUSB and hIDUA have been described previously, ${ }^{13,18,19,41,45}$ as have plasmids for co-delivery of expression cassettes for SB transposases, pCMVSB11, mini(m)Ub-SB11, ${ }^{19,46}$ and pCMV-SB100X. ${ }^{47}$ Liver-specific promoter (LSP) ApoEHCRhAAT ${ }^{40}$ was a gift from Dr. Mark Kay (Stanford University, CA). The SB transposon pKT2/ApoEHCRhAATcGUSB was engineered by inserting the full-length canine (c)GUSB into a unique EcoRI site of the pKT2-ApoE-hAAT-BGintron plasmid. ${ }^{13}$ The plasmid containing $c G U S B$ was a gift from Dr. Kathy Ponder (Washington University, St. Louis, MO). Prior to injection into dogs, plasmids were hydrodynamically infused into $\mathrm{C} 57 \mathrm{BL} / 6$ mice to ensure transgene expression and transposition. 
Table 1. Summary of balloon catheter-mediated DNA delivery to liver in dogs

\begin{tabular}{|c|c|c|c|c|c|c|c|}
\hline Dog ID/infusion ${ }^{\mathrm{a}}$ & Age, months & Weight, kg & $D N A, m g(\mathrm{mg} / \mathrm{kg})$ & Route of delivery ${ }^{b}$ & Rate & $\begin{array}{c}\text { Pressure } \\
\text { peak, } \mathrm{mmHg}\end{array}$ & $\begin{array}{c}\text { Peak } \\
\text { expression }^{\mathrm{c}}(\text { fold })^{\mathrm{d}}\end{array}$ \\
\hline CSEAP & & & & & & & $\mathrm{ng} / \mathrm{mL}$ \\
\hline $9-2$ & 10 & 9.1 & $12.6(1.4)$ & LHV & $202 / 18 s$ & 140 & $8.0(215)$ \\
\hline 17 & 4.5 & 5.8 & $11.6(1.4)$ & LHV & $199 \mathrm{~mL} / 18 \mathrm{~s}$ & 114 & $8.5(104)$ \\
\hline $18-1$ & 3.8 & 6.2 & $12.4(2)$ & LHV & $195 \mathrm{~mL} / 8 \mathrm{~s}$ & N/A & $2.2(64)$ \\
\hline $18-2$ & 11 & 10.1 & $20(2)$ & LHV & $198 \mathrm{~mL} / 8 \mathrm{~s}$ & 193 & $3.0(87)$ \\
\hline $24-2$ & 8 & 9.9 & $20(2)$ & LHV & $200 \mathrm{~mL} / 8 \mathrm{~s}$ & 160 & $1.0(20)$ \\
\hline$c F I X-m y c$ & & & & & & & $\mathrm{ng} / \mathrm{mL}$ \\
\hline $26-1$ & 5 & 6.1 & $14.6(2.4)$ & LHV & $220 \mathrm{~mL} / 10 \mathrm{~s}$ & 150 & $1935(0.4)$ \\
\hline $26-2$ & 9 & 9.2 & $22.1(2.4)$ & LHV & $300 \mathrm{~mL} / 10 \mathrm{~s}$ & 250 & $887(0.2)$ \\
\hline GUSB & & & & & & & nmoles $4 \mathrm{MU} / \mathrm{mL} / \mathrm{h}$ \\
\hline 16 & 4.3 & 5.2 & $10.4(2)$ & LHV & $130 \mathrm{~mL} / 8 \mathrm{~s}$ & 111 & $\leq \mathrm{WT}$ \\
\hline
\end{tabular}

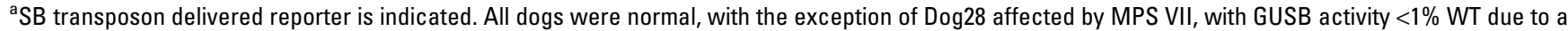
missense R166H mutation.

bIVC, DNA delivery to the entire liver via inferior vena; LHV, delivery to the left liver side via left hepatic vein.

${ }^{\mathrm{c}}$ Peak of reporter protein or activity on days $2-4$ post treatment.

${ }^{\mathrm{d}}$ For $c S E A P$-treated dogs, fold increase in activity relative to pre-injection activity level. For FIXmyc-treated dogs, fold increase in FIX protein relative to a WT $\operatorname{dog}\left(5000 \mathrm{ng} / \mathrm{mL}^{72}\right)$. For GUSB-treated dogs, fold increase in GUSB activity compared to the WT untreated control dog (about $100 \mathrm{nmoles} 4 \mathrm{MU} / \mathrm{mL} / \mathrm{h}$ ) determined in the same study, as the treated dog.

FIX, factor IX; GUSB, $\beta$-glucuronidase; IDUA, $\alpha$-L-iduronidase; IVC, inferior vena cava; LHV, left hepatic vein; N/A, not available; SB, Sleeping Beauty, WT, wild type.

\section{Blood and tissue collection}

Heparinized venous blood samples were collected before, during, and after the procedure for analysis, as described below. Plasma was prepared for enzyme assay, and whole-blood aliquots were shipped to the Marshfield Labs (Marshfield, WI) for complete blood chemistries including alanine transaminase (ALT) and aspartate transaminase (AST) level determination. At the end of each experiment, dogs were given heparin at $150 \mathrm{units} / \mathrm{kg}$ i.v. and anesthetized with propofol at $2-6 \mathrm{mg} / \mathrm{kg}$ i.v. The animals were euthanized using euthasol at $1 \mathrm{~mL}$ (390 mg pentobarbital $+50 \mathrm{mg}$ phenytoin)/ $4.5 \mathrm{~kg}$. The liver was perfused with $1,000 \mathrm{~mL}$ of saline to attain virtually uncolored outflow, and then 20-100 liver samples were collected for individual analysis. Plasma and tissue samples were stored at $-80^{\circ} \mathrm{C}$.

\section{cSEAP enzyme assay}

Plasma samples were heated for $10 \mathrm{~min}$ at $65^{\circ} \mathrm{C}$ and then assayed for alkaline phosphatase enzymatic activity using Applied Biosystems Tropix ${ }^{\circledR}$ Phospha phospholuminescent substrate (Thermo Fisher Scientific, Waltham, MA) with human SEAP as a standard for determination of results in $\mathrm{ng} / \mathrm{mL}$.

\section{cFIX-myc enzyme-linked immunosorbent assay}

Canine plasma samples were assayed in duplicate by sandwich enzyme-linked immunosorbent assay (ELISA) for canine FIX-myc protein. High binding polystyrene 96-well plates (Costar 3369) were coated with goat polyclonal anti-myc tag capture antibody (Ab9132; Abcam, Cambridge, United Kingdom), diluted to $2.5 \mu \mathrm{g} / \mathrm{mL}$ in $50 \mathrm{mM}$ of carbonate buffer, $\mathrm{pH} 9.6$, and incubated overnight at $4^{\circ} \mathrm{C}$. Plasma samples were diluted 20 -fold with sample diluent $(100 \mathrm{mM}$ of HEPES, $100 \mathrm{mM}$ of $\mathrm{NaCl}, 10 \mathrm{mM}$ of disodium EDTA, $150 \mathrm{mM}$ of bovine serum albumin, and $0.1 \%$ Tween-20, final $\mathrm{pH} 7.2$ ). A total of $100 \mu \mathrm{L}$ was added to each well, and the plate was incubated for $1 \mathrm{~h}$ at room temperature. After three washes with wash buffer (Bio-Techne, Minneapolis, MN; \#895126), detection antibody was added $(100 \mu \mathrm{L}$ at $1 / 400$ dilution of horseradish peroxidase-conjugated anti-canine FIX antibody, CFIX-EIA-D; Enzyme Research Laboratories, South Bend, IN), and the plate was incubated for $1 \mathrm{~h}$ at room temperature. After three washes with BioTechne wash buffer, $100 \mu \mathrm{L}$ of tetramethylbenzidine/ hydrogen peroxide substrate (Bio-Techne) was added to each well and stopped with $100 \mu \mathrm{L}$ of $2 \mathrm{~N}$ sulfuric acid after $20 \mathrm{~min}$ at room temperature. Plates were read at 450-490 nm (Spectromax), and cFIX levels 


\section{Plasmid}

Infusion

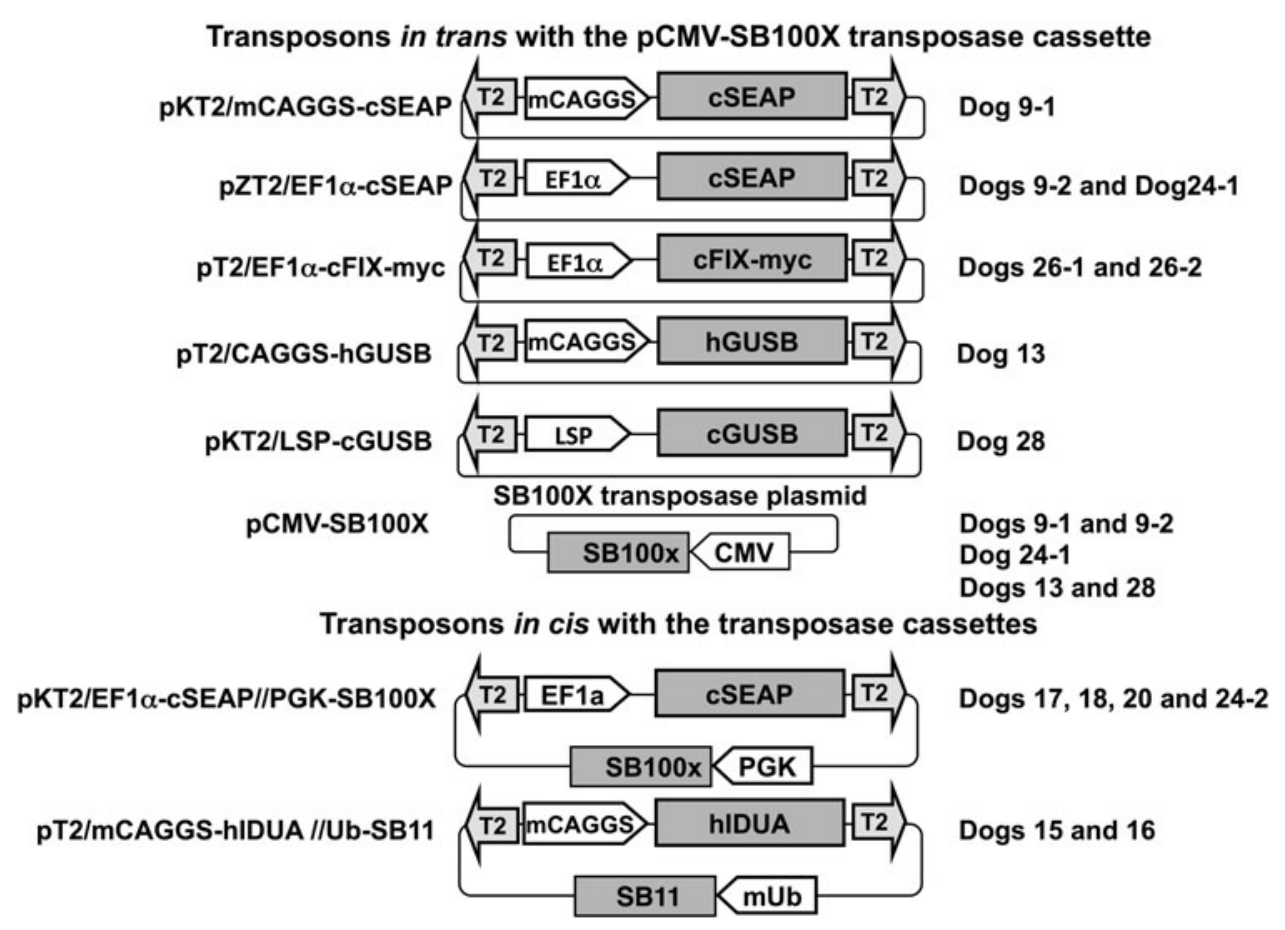

Figure 2. Transposon and transposase-encoding plasmids. Transposons contain T2 inverted terminal repeats (lightly shaded arrows) and a reporter gene sequence (darker shaded boxes), encoding canine secreted alkaline phosphatase (cSEAP), canine factor IX (cFIX), human or canine $\beta$-glucuronidase (h or cGUSB), or human $\alpha$-L-iduronidase (hIDUA). Reporter gene expression was regulated by the ubiquitously expressed CAGGS or mini(m)CAGGS promoters, ${ }^{19,46}$ liver-specific promoter (LSP) ApoEHCRhAAT, ${ }^{40}$ or by a CpG-less variant of EF1 $\alpha$ promoter (unshaded block arrows); pKT2/EF1 $\alpha$-cSEAP//PGK-SB100X ${ }^{41}$ contains a PGK-regulated $S B 100 X$ gene, exterior to the cSEAP-encoding transposon, while pT2/mCAGGS-hIDUA//mUb-SB11 19 contains a mini-ubiquitin-regulated $S B 11$ gene ${ }^{45}$ downstream of the transgene-encoding transposon (i.e., in cis). For the other transposons, Sleeping Beauty (SB) transposase was provided in trans by co-infusion of pCMV-SB100X plasmid. ${ }^{47}$ Plasmids with pKT2- or pZT2-backbones were kanamycin- or zeocin-resistant, respectively; other plasmids were ampicillin-resistant.

were reported in $\mathrm{ng} / \mathrm{mL}$. To generate a standard for canine FIX-myc, plasma samples were pooled after collection from three mice 1 day after hydrodynamic injection with $\mathrm{pKT} 2 / \mathrm{EF} 1 \alpha$-cFIX-myc plasmid. The concentration of total cFIX in the pooled plasma sample was determined by ELISA (CFIX-EIA; Enzyme Research Labs, South Bend, IN). Freshly diluted mouse plasma was used as a standard in each ELISA assay.

\section{IDUA and GUSB enzyme assays}

IDUA and GUSB activities were measured in tissue homogenates and plasma using 4methylumbelliferyl- $\beta$-D-glucuronide (Sigma-Aldrich) and 4-methylumbelliferyl- $\alpha$-iduronide (Glycosynth, Warrington, United Kingdom), respectively, in fluorometric assays using a 96-well plate reader, as previously described. ${ }^{13,48}$

\section{Quantification of liver glycosoaminoglycans}

Liver lysates prepared from collected pieces were incubated overnight with Proteinase K, DNase I, and RNase, as previously described. ${ }^{48}$ Glycosoami- noglycan (GAG) concentrations were determined using the Blyscan Sulfated Glycosaminoglycan Assay (Accurate Chemical \& Scientific Corp., Westbury, NY) according to the manufacturer's instructions.

\section{Polymerase chain reaction analysis}

DNA copy numbers of GUSB and IDUA were determined by real-time quantitative polymerase chain reaction (qPCR) using $2 \mathrm{X} \mathrm{IQ"SYBR} \mathrm{Green}$ Supermix (Bio-Rad Laboratories, Hercules, CA), as previously described. ${ }^{13,19}$ DNA was isolated by phenol-chloroform extraction from approximately $50 \mathrm{mg}$ of liver tissue samples pulverized in liquid nitrogen. Canine glyceraldehyde-3-phosphate dehydrogenase ( $c G A P D H$ ) sequence served as an internal control for genomic DNA content. Canine $G A P D H$ standard curve consisted of serial dilutions of dog genomic DNA. The canine $c S E A P$ qPCR was performed using Taqman technology, as previously described. ${ }^{41}$ The limit of detection was $2 \times 10^{-4}$ copies per diploid genome equivalent in dog liver. 
Quantitative image analysis of hGUSB transgene expression and lysosomal storage in the liver

Histochemical localization of GUSB was performed using AS-BI-naphthol- $\beta$-D-glucuronic acid (SigmaAldrich), as described. ${ }^{49}$ Stained tissue samples were photographed at $20 \times$ magnification using a digital camera (Nikon, Melville, NY). Images were contrast enhanced so as to delineate image details clearly using Photoshop 6.0 image processing software (Adobe Systems, San Jose, CA), as previously described. ${ }^{18}$

\section{Transmission electron microscopy and toluidine blue staining}

For detection of storage vacuoles, liver tissue samples of approximately $2 \mathrm{~mm} \times 2 \mathrm{~mm} \times 2 \mathrm{~mm}$ collected at necropsy were immediately fixed with $2.5 \%$ glutaraldehyde overnight at $4^{\circ} \mathrm{C}$. After washing three times with $0.1 \mathrm{M}$ of sodium cacodylate, the samples were post fixed with $1 \% \mathrm{OsO}_{4}$ for $1 \mathrm{~h}$, rinsed three times, and dehydrated in a graded series of ethanol solutions. The samples were embedded in Epon812 resin. Ultrathin sections $(65 \mathrm{~nm})$ were stained with uranyl acetate and lead citrate, and then examined by JEOL 1200EX II electron microscopy. Thin sections were cut at $1 \mathrm{~mm}$ from the same blocks, stained with toluidine blue, and evaluated for lysosomal distension. ${ }^{18}$

\section{Statistical analysis}

Data were analyzed using GraphPad Prism v6.0 (GraphPad Software, Inc., San Diego, CA). The significance of differences between groups was determined based on two-tailed $p$-values obtained with Welch's $t$-test. A $p$-value of $<0.05$ was considered statistically significant.

\section{RESULTS}

\section{Transient $\mathrm{GdCl}_{3}$ regimen prolonged persistence of the cSEAP reporter in plasma}

To evaluate the impact of immunosuppression on duration of cSEAP expression, dogs were treated with immunosuppressive drugs that had been efficient in the mouse gene therapy studies. ${ }^{13,18,50}$ Dog17 was administered cyclophosphamide (CP) i.v. at a dose of $10 \mathrm{mg} / \mathrm{kg} 1$ day before DNA infusion and then once weekly for 30 days. In addition, dexamethasone (Dex), a commonly used postoperative anti-inflammatory agent, was injected at a dose of $1 \mathrm{mg} / \mathrm{kg}$ for 10 days, starting 1 day prior to plasmid infusion. This combination of drugs did not prolong cSEAP expression (Table 2). Figure 3B shows that the profile of cSEAP activity in Dog 17 is virtually indistinguishable from that in Dog9, which was not immune suppressed. Therefore, the immunosuppression regimen was modified to add gadolinium chloride $\left(\mathrm{GdCl}_{3}\right)$, an agent that blocks liver and spleen macrophages. $\mathrm{GdCl}_{3}$ was previously shown to extend IDUA expression in IDUAdeficient mice. ${ }^{18} \mathrm{GdCl}_{3} \times 6 \mathrm{H} 2 \mathrm{O}$ at a dose of $10 \mathrm{mg} / \mathrm{kg}$ was administered i.v. 1 day prior and immediately prior to plasmid infusion and then twice weekly for 30 days. In Dog18, it was observed that the addi-

Table 2. Maintenance of transgene expression in dogs with respect to immunomodulation regimen and elevation of ALT and AST

\begin{tabular}{|c|c|c|c|c|c|}
\hline \multirow[b]{2}{*}{ Dog/infusion } & \multirow[b]{2}{*}{ Infused vectors } & \multirow[b]{2}{*}{ Immunomodulation } & \multicolumn{2}{|c|}{ Transaminase peak-fold baseline ${ }^{a}$} & \multirow[b]{2}{*}{$T_{1 / 2}^{\mathrm{b}}$} \\
\hline & & & $A L T$ & $A S T$ & \\
\hline & SEAP transposons & & & & \\
\hline $9-1$ & pKT2/mCAGGS-cSEAP + pCMV-SB100X & None & 231 & 114 & 6 days \\
\hline $9-2$ & pZT2/EF1 $\alpha$-cSEAP + pCMV-SB100X & None & 173 & 128 & 6 days \\
\hline 17 & pKT2/EF1 $\alpha$-cSEAP//PGK-SB100X & $\mathrm{CP}+\mathrm{Dex}$ & 193 & 125 & 6 days \\
\hline $18-1$ & pKT2/EF1 $\alpha$-cSEAP//PGK-SB100X & $\mathrm{CP}+\mathrm{Dex}+\mathrm{GdCl}_{3}$ & 14 & 8 & 15 days \\
\hline $18-2$ & pKT2/EF1 $\alpha$-cSEAP//PGK-SB100X & $\mathrm{GdCl}_{3}$ & 82 & 59 & 6 days \\
\hline 20 & pKT2/EF1 $\alpha$-cSEAP//PGK-SB100X & $\mathrm{GdCl}_{3}$ & 18 & 18 & 15 days \\
\hline $24-1$ & pZT2/EF1 $\alpha-c S E A P+p C M V-S B 100 X$ & $\mathrm{GdCl}_{3}$ & 164 & 44 & 8 days \\
\hline \multirow[t]{2}{*}{$24-2$} & pKT2/EF1 $\alpha$-cSEAP//PGK-SB100X & $\mathrm{GdCl}_{3}$ & 208 & 66 & 6 days \\
\hline & FIX transposon & & & & \\
\hline $26-1$ & pKT2/EF1 $\alpha$-cFIX-myc + pCMV-SB100X & $\mathrm{GdCl}_{3}$ & 351 & 127 & 20 days \\
\hline \multirow[t]{2}{*}{$26-2$} & pKT2/EF1 $\alpha$-cFIX-myc + pCMV-SB100X & $\mathrm{GdCl}_{3}$ & 308 & 146 & 4 days \\
\hline & GUSB transposons & & & & \\
\hline 13 & pT2/CAGGS-hGUSB + pCMV-SB100X & None & 94 & 65 & - \\
\hline \multirow[t]{2}{*}{28} & pKT2/LSP-cGUSB + pCMV-SB100X & $\mathrm{GdCl}_{3}$, incomplete & 62 & 106 & $18 \mathrm{~h}$ \\
\hline & IDUA transposon & & & & \\
\hline 15 & pT2/mCAGGS-hIDUA//mUb-SB11 & None & 42 & 25 & 一 \\
\hline 16 & pT2/mCAGGS-hIDUA//mUb-SB11 & None & 189 & 106 & - \\
\hline
\end{tabular}

${ }^{a}$ Fold increase over pre-first infusion ALT and AST level, respectively, in the same dog; normal levels in dogs: ALT 14-151 IU/L; AST 18-86 IU/L.

${ }^{b}$ Half-life of protein/enzyme activity in plasma.

ALT, alanine aminotransferase; AST, aspartate transaminase. 


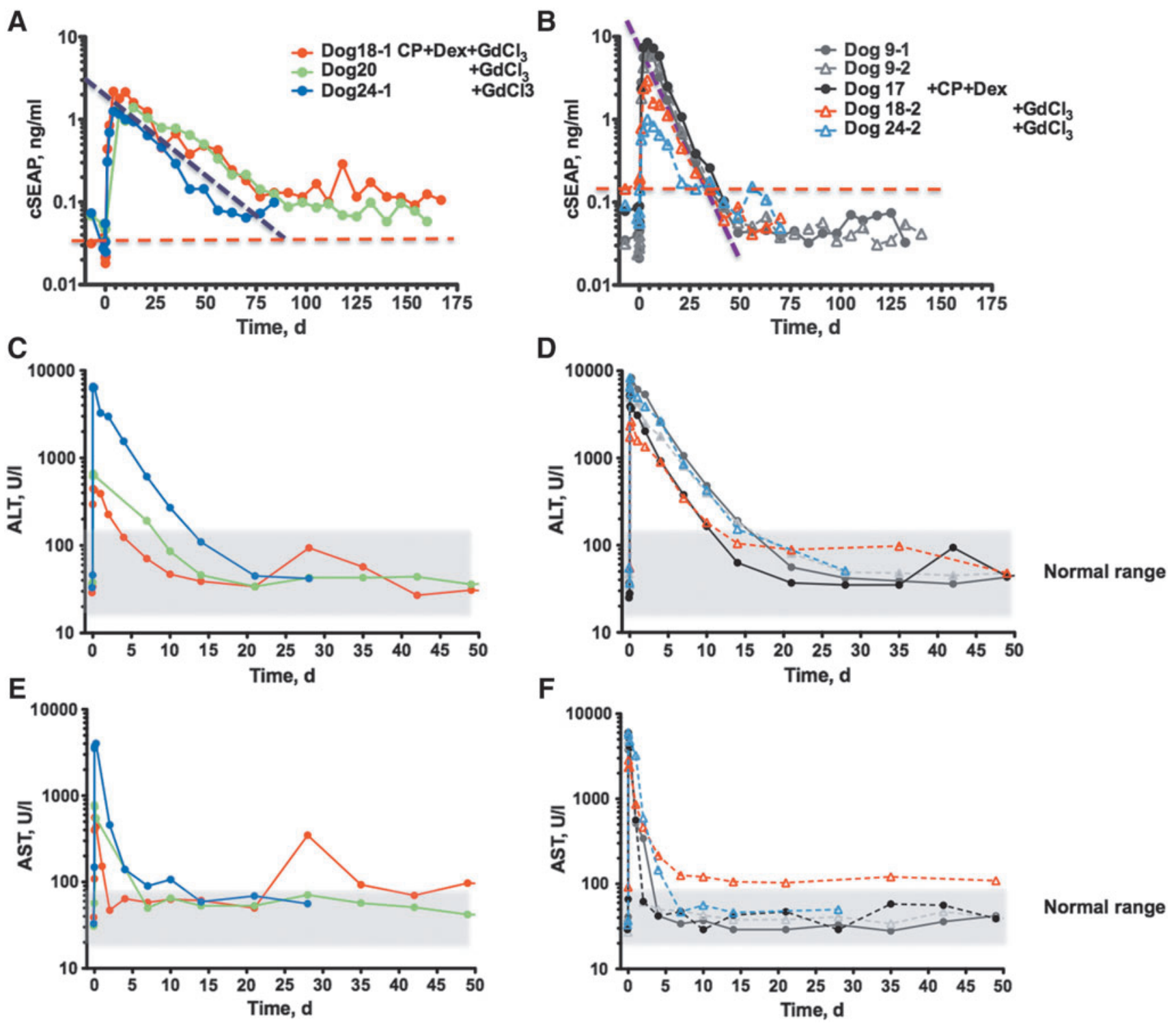

Figure 3. Transgene expression and liver toxicity in dogs infused with $c S E A P$ transposons with and without $\mathrm{GdCl}_{3}$ immunomodulation. (A and $\mathbf{B}$ ) cSEAP time course in dog plasma after DNA infusion. Plasma cSEAP levels are shown at weekly intervals following infusion of transposon plus transposase-encoding DNA as described in the text. Profiles of cSEAP expression following two separate infusions into Dog9 (B) represent the most successful cSEAP deliveries in the absence of $\mathrm{GdCl}_{3}$ treatment and serve as reference profiles. The dashed purple lines (A) and (B) are guides to help visualize rates of decline in cSEAP activity. The baselines for cSEAP in each dog represent the calculated mean value prior to the first infusion. The red dashed line indicates the baseline cSEAP level in Dog18 prior to the first (A) and second (B) infusion. Note that before the second infusion (i.e., 167 days after the first treatment), the baseline in Dog18 is about fourfold higher than that before the initial infusion. (C and D) Alanine transaminase (ALT) profiles correspond to infusions in (A) and (B), respectively. (E and F) Aspartate transaminase (AST) profiles correspond to infusions in (A) and (B), respectively.

tion of $\mathrm{GdCl}_{3}$ treatment prolonged cSEAP expression up to 5.5 months. cSEAP expression in this animal was associated with a gradual decline, but appeared to stabilize after about 2 months at approximately fourfold higher than the baseline level (Fig. 3A). The half-life $\left(\mathrm{T}_{1 / 2}\right)$ of cSEAP activity profiles was calculated to quantify the decline of expression in plasma independently of peak height. ${ }^{13} \mathrm{GdCl}_{3}$ regimen extended the cSEAP halflife in plasma by about 2.5-fold, from 6 to 15 days (Table 2).
Next, the study tested if $\mathrm{GdCl}_{3}$ alone would extend the profile of cSEAP activity after hydrodynamic injection of $c S E A P$ transposon DNA to dogs. Indeed, in the next two treated dogs (Dog20 and Dog24), the cSEAP expression half-life values were higher than those observed in Dog9 and Dog17, but re-infusion in Dog24 (Dog24-2) did not result in prolonged transgene expression. The same effect was observed in Dog18 (Dog18-2) upon transposon re-infusion on day 167. Despite repeated $\mathrm{GdCl}_{3}$ regimen, $\mathrm{cSEAP}$ declined as rapidly $\left(\mathrm{T}_{1 / 2} \approx 6\right.$ days $)$ 
as in Dog9 and Dog17 that did not receive $\mathrm{GdCl}_{3}$. Rapid decay of cSEAP expression upon DNA reinfusion cannot be explained by lower transposon delivery. Plasma cSEAP maximal levels after the first and second infusions were comparable, suggesting that the increased liver volume at the time of the second infusion had little effect on gene delivery (Dog9, Dog17, Dog18, and Dog24; Table 1).

Noteworthy, at the peak of activity (2-4 days post infusion), nine separate infusions of $c S E A P$ transposon plasmids resulted in cSEAP plasma levels 14- to 200-fold greater than the pre-infusion level of heat-stable alkaline phosphatase (Table 1 and Fig. 3A and B), supporting the data of Hyland et $a l .{ }^{41}$ There was no relationship between recorded peak i.v. pressure and maximum plasma cSEAP, which suggests that high pressure alone is not a critical parameter for extent of DNA delivery to cells in the liver.

DNA qPCR showed that transposon plasmid encoding cSEAP peaked in plasma within 1 day post infusion and was rapidly cleared from the blood by 5 days (Supplementary Fig. S1A; Supplementary Data are available online at www.liebertpub.com/ hum). At necropsy, up to 8 months after the first infusion and 3 months after the re-infusion, the abundance of $c S E A P$ transposon plasmid was between 0.001 and 0.01 copies/genome equivalent, similar to levels of transposon plasmid measured in Dog9 liver samples, ${ }^{41}$ whereas negative control samples from the right liver lobes yielded qPCR signals with the geometric mean nearing the detection limit (Supplementary Fig. S1).

\section{Impact of transient hepatocellular toxicity on transgene expression}

Achieving prolonged expression of cSEAP after a single infusion of vector permitted factors to be evaluated that may affect transgene expression following balloon catheter-mediated delivery in dogs. Biomarkers of liver health and pathology, ALT and AST, showed a dramatic short-term increase in all treated dogs (Table 2), signaling inflammation and cell damage. ${ }^{51,52}$ ALT and AST values returned to normal within 2 weeks for ALT and a few days for AST (Fig. 3C-F and Supplementary Fig. S2B and C), in agreement with previous results. ${ }^{41}$ Evaluation of the liver by ultrasound immediately after infusion and by computed tomography scan 2 days after infusion did not indicate any rupture or other visible injury to the liver. The animals were clinically healthy starting the day after the infusion and continuing through the end of the follow-up, which lasted as long as 5.5 months.
The transient increase of ALT and AST in response to plasmid infusion varied among dogs (Fig. 3C-F and Table 2) and appeared to be inversely associated with cSEAP half-life following a single DNA infusion. The dogs that had the longest sustained cSEAP expression, Dog18-1 and Dog20, had the lowest increases of ALT and AST (8- to 18-fold), while Dog 24-1, which had a relatively shorter cSEAP half-life, exhibited a 44- and 164fold increase of ALT and AST, respectively (Table 2). These data suggest that liver inflammation and cell damage curtail expression, although the small number of dogs does not support a statistically sound correlation. However, repeat plasmid administration with $\mathrm{GdCl}_{3}$ treatment (Dog18-2, Dog24-2, and Dog26-2) led to overall higher increases of ALT and AST. These observations, together with lack of prolonged transgene expression, despite $\mathrm{GdCl}_{3}$ immunomodulation upon vector re-infusion, also strongly suggest that an increase of hepatocellular toxicity is associated with a loss of immunosuppressive effect. Notably, in Dog9, which did not receive $\mathrm{GdCl}_{3}$, the rate of cSEAP decline was equally rapid after the first and the second infusion, and the respective ALT and AST profiles were similar after both infusions.

\section{SB-mediated expression of therapeutic proteins with and without $\mathrm{GdCl}_{3}$ immunomodulation}

To test if immunosuppression would prolong expression of a potentially therapeutic transgene, transposon-plasmid encoding myc-tagged cFIX was infused into $\mathrm{GdCl}_{3}$-treated Dog26, which resulted in a peak level of $\sim 2 \mu \mathrm{g} / \mathrm{mL}$, about $40 \%$ of the endogenous level of clotting factor. The protein had a half-life of 20 days (Tables 1 and 2 and Supplementary Fig. S2A). Thus, immunomodulation with $\mathrm{GdCl}_{3}$ prolonged cSEAP and cFIX expression in all dogs after a single transposon infusion.

Upon re-infusion of the cFIX-encoding transposon with $\mathrm{GdCl}_{3}$ treatment (Dog26-2), a rapid decline in circulating transgenic protein was observed, which peaked at $20 \%$ the endogenous level but became undetectable by 3 weeks post infusion. These results were similar to those obtained with reinfusion of $c S E A P$ transposons. Similarly, repeat plasmid administration led to an overall higher increase of ALT and AST (Supplementary Fig. S2A), supporting the observations that an increase in hepatocellular toxicity is associated with a loss of immunosuppressive effect.

The study further examined whether hydrodynamic delivery of transposons would be therapeutic in dogs for MPS I and VII, as it had previously been 
demonstrated in mice. ${ }^{13,18,19}$ The goal of short-term experiments was to evaluate peak expression levels of transgenic lysosomal enzymes GUSB and IDUA, respectively, as well as transposition in the liver, prior to the onset of adaptive immune response. The transposons were co-delivered with a SB transposase expression cassette that was either on the same or on a separate plasmid, referred to as cis- or transconfiguration, respectively (Fig. 2 and Table 2). The one-plasmid SB configuration ensures co-expression of the transgene and SB transposase in the same cell, thus increasing the chance of transposition. The twoplasmid configuration increases the likelihood of delivery to the nucleus due to a smaller plasmid size and also permits alteration of relative transposon and transposase dosing, which can improve transposition efficiency. ${ }^{10,12}$ Two versions of SB transposase were used: $\mathrm{SB}^{4} 1^{46}$ or SB100X. ${ }^{47}$ The latter mediates a 10 - to 20 -fold higher rate of transposition in mice after hydrodynamic delivery. ${ }^{13}$

The transposon plasmid pT2/CAGGS-hGUSB (Fig. 2) that drove strong expression of human GUSB in mice ${ }^{18}$ was infused into the whole liver (Fig. 1A) of a young adult normal dog, along with pCMV-SB100X in trans (Dog13). The animal was euthanized 4 days after infusion at which point GUSB activity in plasma was $350 \mathrm{nmoles} 4 \mathrm{MU} / \mathrm{mL} / \mathrm{h}$, about 3.5-fold above the background enzyme activity of an untreated WT dog (Fig. 4A and Table 1). One hundred tissue samples were collected from the treated dog, and all contained measurable levels of transposon DNA that spanned 0.01-0.8 copies/genome equivalent (Fig. $4 \mathrm{C}$ and D), with an average of 0.08 copies/genome equivalent. Peak expression in the GUSB-treated Dog13 liver was $<5 \%$ the peak activity in mice infused with the same transposon: 350 versus 9,400 nmoles $4 \mathrm{MU} / \mathrm{mL} / \mathrm{h}$.

Of 100 liver samples, three contained quantifiable levels of transposon-excision product (EP) at about 0.002 copies/genome equivalent, which corresponded to 2-3\% EP/transposon molecules (0.002/ 0.08 ). This value is within the range previously reported for mouse liver when $S B 11$ was used ${ }^{19}$ and implies that transposition was functional in the dog liver, although at about 20 times lower efficiency than in mice treated with $S B 100 X .^{13}$

The next two dogs were treated with the IDUAexpressing transposon configured in cis. This transposon was previously demonstrated to mediate strong long-term expression in male NOD/ SCID MPS VII mice. ${ }^{19}$ The plasmids were infused into the left portion of the liver. The rationale for targeting only the left portion of the liver was to (1) minimize invasiveness, and (2) achieve a higher ratio of volume of infused solution to liver mass.
Following hydrodynamic infusion into the left hepatic vein, normal male dogs (Dog15 and Dog16; Table 1) were sacrificed at days 4 and 7 , respectively. Fifty tissue samples were collected from the left lateral liver lobe, and 10 samples were collected from the right liver portion. DNA qPCR confirmed delivery to the left lateral lobe, which was 20fold higher than that to the right liver samples $(p<0.0001)$. Focused delivery of $h I D U A$ transgene to the left side of the liver in Dog15 and Dog16 resulted, on average, in 0.4 copies/genome equivalent, a fivefold higher transgene frequency compared to that of $h G U S B$ transgene in Dog13, in which the whole liver was infused (Fig. 4C and D). However, there was no detectable increase in IDUA enzymatic activity above normal levels. These data suggest that if there was any transgenic expression of hIDUA, it was lower than the innate IDUA activity in unaffected Dog15 and Dog16. No excision products were detected.

Catheter-mediated delivery of GUSB-encoding transposons into a canine model of MPS VII was evaluated, ${ }^{27,28}$ in which there is $<1 \%$ of normal GUSB activity due to a missense $\mathrm{R} 166 \mathrm{H}$ mutation. This dog model recapitulates many features of MPS VII in humans, including hepatomegaly caused by accumulation of storage material inside the lysosomes of liver cells. MPSVII Dog28 was treated with a triple amount of DNA $(7.6 \mathrm{mg}$ of DNA $/ \mathrm{kg}$; Table 1) that might approximately compensate for the increased liver volume due to hepatomegaly. To minimize immune responses, transposon pKT2/LSP-cGUSB containing the "self"transgene canine $G U S B$ and liver-specific promoter ApoEhCRhAAT that directs strong, hepatocyterestricted transgene expression in $\operatorname{dogs}^{40}$ and mice was constructed. ${ }^{13}$ A similar transposon carrying hIDUA and also co-delivered with pCMV-SB100X mediated sustained expression $\geq 100$-fold WT in immunosuppressed C57BL/6 mice in a year-long study.

Dog28 was treated with $\mathrm{GdCl}_{3}$, but the regimen was incomplete. A week after DNA infusion, the port had to be removed because of infection. In this $\mathrm{dog}$, the veins were hard to access and became unusable after each injection of $\mathrm{GdCl}_{3}$, likely due to its leakage into the tissue surrounding the blood vessel. Of note, the MPS VII dog was the only one in this study where there was difficulty accessing the veins.

Plasma GUSB activity in Dog28 was detectable on days 1-5 post infusion, peaking on day 2 at $50 \%$ of activity level in the unaffected sibling (Table 1 and Fig. 4B). GUSB activity was not detectable thereafter, and 3 weeks post treatment, the dog was euthanized. The half-life of hGUSB in plasma 
A

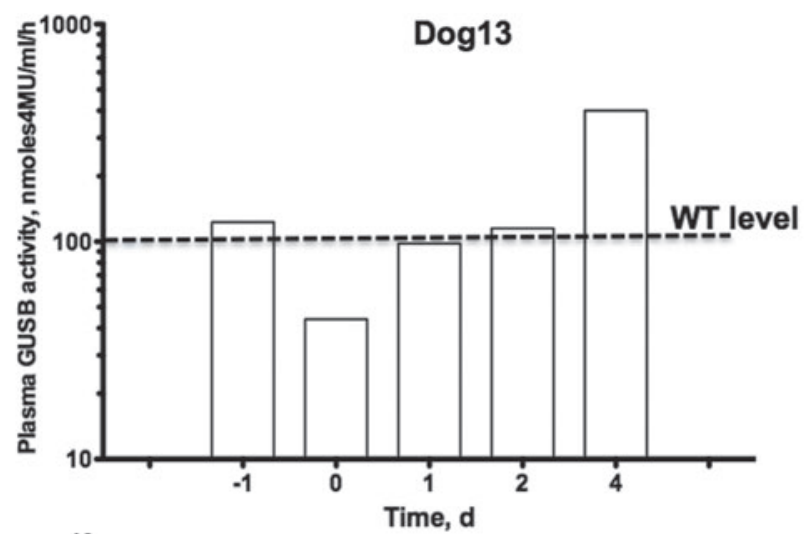

C

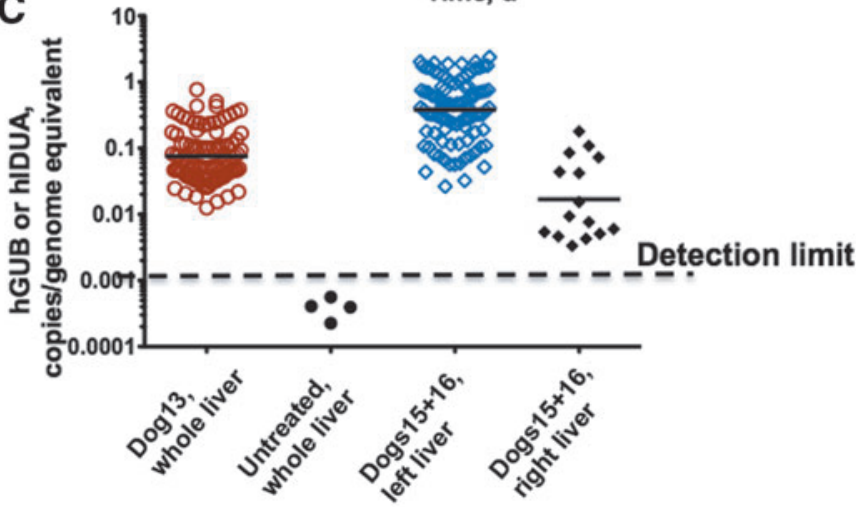

E

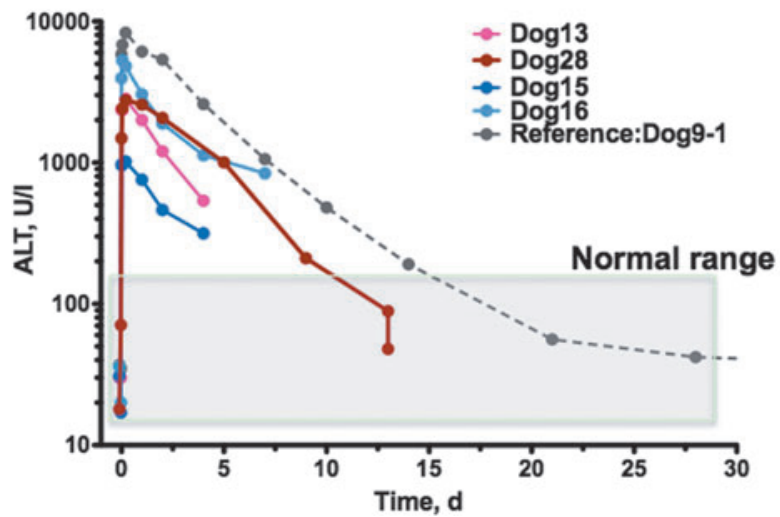

B

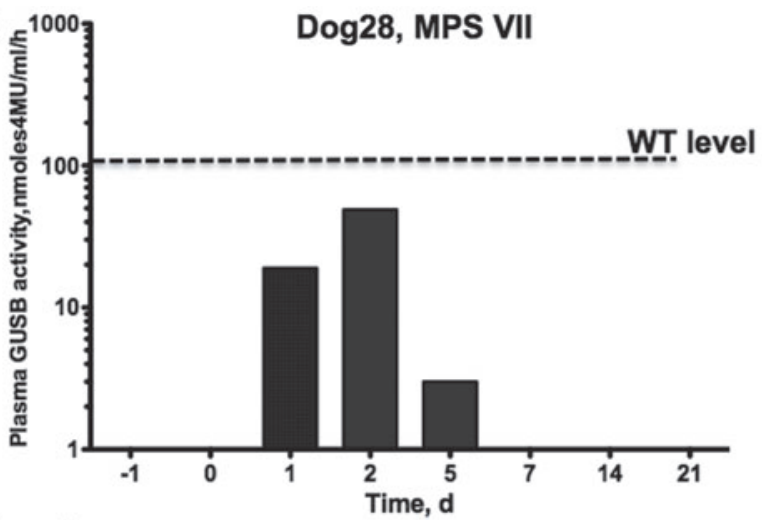

D

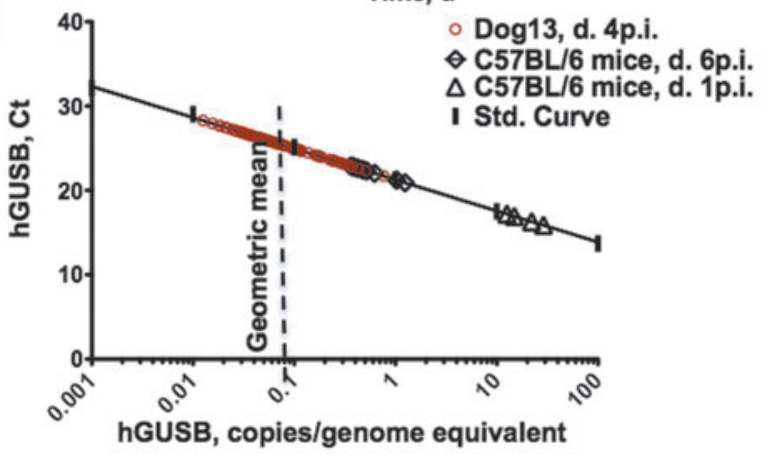

F

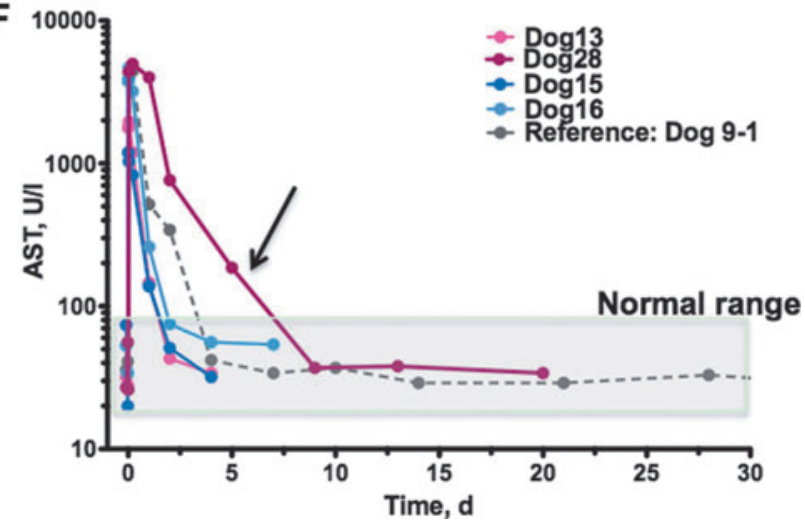

Figure 4. Delivery of GUSB and IDUA to dog liver without $\mathrm{GdCl}_{3}$ immunomodulation resulted in low-level, short-term expression. (A) Plasma GUSB activity in Dog13 before and after hydrodynamic infusion of GUSB-expressing SB transposon. (B) GUSB activity in plasma of MPS VII affected Dog28 before and after hydrodynamic infusion of GUSB-expressing SB transposon. Background plasma GUSB activity was $<1 \mathrm{nmole} 4 \mathrm{MU} / \mathrm{mL} / \mathrm{h}$. (C) Quantitative polymerase chain reaction (qPCR) for $h$ GUSB and $h I D U A$ transgenes in liver of wild-type dogs harvested 4-7 days after infusion of either pT2/CAGGS-hGUSB + pCMV-SB100X or pT2/mCAGGS-IDUA//UB-SB11, respectively. Horizontal lines indicate geometric mean values. The negative control for Dog13 was DNA prepared from an untreated dog; the negative control for left-liver-targeted Dog15 and Dog16 was prepared from tissue samples collected from the right-side liver. (D) Transgene frequency in liver of the $h G U S B$-treated dog versus mouse. Dog DNA samples were prepared from pieces of Dog 13 liver harvested 4 days post infusion; mouse DNA samples were prepared from individual livers obtained either at day 1 or at day 6 post infusion, as indicated in the key. Transgene frequencies estimates were based on SYBR Green qPCR assay. (E) ALT profiles following balloon-catheter-mediated GUSB and IDUA transposon infusion in dogs. (F) AST profiles following balloon-catheter-mediated GUSB and IDUA transposon infusion in dogs. Arrow points to the elevated AST in MPS VII Dog28. ALT and AST profiles of Dog9, representing the most successful transgene delivery in the absence of $\mathrm{GdCl}_{3}$ treatment, serve as reference profiles.

was estimated at about $18 \mathrm{~h}-10$ times shorter than $\operatorname{cSEAP}\left(\mathrm{T}_{1 / 2} \approx 6\right.$ days $)$.

Liver samples from Dog28 were collected and assayed for enzymatic activity, GAG accumulation, and GUSB gene frequency. GUSB activity was not detected in either plasma or liver lysates by $4 \mathrm{MU}$ based enzyme assay. Quantitative assay of GAG levels in the treated liver samples showed no reduction in storage. Representative transmission electron micrographs and toluidine blue-stained liver tissue sections exhibited full pathology similar to that of liver samples from untreated animals (Supplementary Fig. S3A and B). However, GUSBexpressing cells were visualized in histochemically 
stained sections of the left lateral lobe at a frequency of $1: 10,000-1: 100,000$ cells, whereas no stained cells were detected in the untreated control liver tissue (Supplementary Fig. S3C). The low frequency is consistent with the inability to detect $c G U S B$ DNA due to the qPCR assay's sensitivity limit of 1:1,000 genome equivalents. These numbers are also in agreement with the qPCR detection of $c S E A P$ transposon post expression at low but measurable frequencies in all treated dog livers.

Dog28 exhibited transient elevation of transaminases ALT and AST (Fig. 4E and F). While ALT elevation resolved within the time frame of $c S E A P$ - and $c F I X$-injected dogs, elevated AST levels in the MPS VII dog lasted longer than in all normal dogs. It is presumed that the liver in this dog was more prone to damage from hydrodynamic delivery than was the liver in the WT dogs, possibly due to complications associated with hepatomegaly.

\section{DISCUSSION}

This is the first report of prolonged transgene expression of $>4$ months in large animals after nonviral vector delivery. Previously, infusion in rats achieved maintenance of human FIX for 2 months following a modified hydrodynamic injection. ${ }^{53}$ This study reports that expression of reporter cSEAP and therapeutic protein cFIX was extended from 6 to about 24 weeks after a single vector administration, when a transient, 30-day regimen of $\mathrm{GdCl}_{3}$ was administered. Moreover, in one dog, cSEAP expression stabilized at about fourfold greater than the pretreatment level (Dog18-1; Fig. 3A). The lack of an immunosuppressive effect in the MPS VII dog is most probably due to an insufficient dose of $\mathrm{GdCl}_{3}$ caused by problems with accessing blood vessels in the affected dog that may be associated with the tissue properties of the MPS VII animal. Intravenous administration of $\mathrm{GdCl}_{3}$ blocks phagocytosis in the liver and selectively eliminates large Kupffer cells, resident liver macrophages that produce cytokines, and other inflammatory mediators in response to bacterial infection and liver injury. ${ }^{54}$ In rats, Kupffer cells repopulate the liver 3-7 days post treatment, and effectiveness of $\mathrm{GdCl}_{3}$ is not diminished by repeated administration if repopulation is complete. ${ }^{55}$ However, in $\mathrm{GdCl}_{3}$-immunosuppressed dogs, prolonged transgene expression was observed only after the first DNA infusion. Dramatic loss of expression upon vector re-administration, similar to that observed in dogs, has been previously demonstrated in transposon-treated immunosuppressed mice. ${ }^{56}$
Hepatocellular toxicity, while transient, appeared to curtail transgene expression. Thus, following initial vector administration in $\mathrm{GdCl}_{3}$ treated dogs, lower peak levels of liver transaminases ALT and AST were observed in dogs exhibiting a longer duration of transgene expression. However, when vector infusion and $\mathrm{GdCl}_{3}$ treatment were repeated, transgene and ALT and AST profiles were similar to those observed in dogs that were not administered $\mathrm{GdCl}_{3}$.

Nine infusions of $c S E A P$ transposon resulted in up to an approximately 200 -fold increase in the preinfusion level of heat-stable alkaline phosphatase, and two infusions of cFIX transposon attained a level of clotting factor that was up to $40 \%$ of the endogenous level of canine FIX. These results confirmed the reproducibility of the catheter-mediated, non-viral delivery of SB transposons to dogs. The shorter half-life of GUSB compared to cSEAP in dogs treated without immunosuppression is almost certainly due in part to rapid uptake of the lysosomal enzyme via mannose-6-phosphate-mediated endocytosis. ${ }^{57}$ Avid cellular uptake is documented in patients with lysosomal storage diseases treated with bone-marrow transplantation. For example, in MPS I patients, IDUA activity in plasma is below the detection limit, ${ }^{58}$ even after full bone-marrow engraftment, and it takes $>2$ years to reach $35-40 \%$ of the normal control value. ${ }^{59}$

In dogs, transgene expression regulated by the CAGGS promoter achieved its peak level in plasma at 2-4 days post infusion compared to 1 day post infusion in mice. The reason for the difference in appearance of peak expression is unclear. In GUSBand IDUA-treated dogs, the detected number of transgenes per liver cell was 20-100 times lower than that in mice. This lowered efficiency of gene transfer/cell in the dog probably explains the shorter duration of detectable transgene expression 1 week post infusion, since in NOD/SCID mice, expression levels in the plasma drop 5- to 10-fold before stabilization, ${ }^{19}$ which would render expression undetectable were it to happen in dogs.

On the other hand, the long-term experiments with both immune-suppressed and NOD/SCID mice treated with the same transposons as dogs showed that while extended expression drops 5- to 10 -fold below the day +1 level, the transgene copy number drops 30 - to 40 -fold. ${ }^{13,19,60}$ This suggests that $70-80 \%$ of plasmids in the liver are lost, but those that enter nuclei and are expressed are retained at a higher rate. In immunocompetent mice, further loss of activity/transfected cells occurs with the onset of adaptive immune responses. These observations emphasize the importance of finding 
effective immunosuppression for dogs that are hydrodynamically infused with naked DNA.

As has been previously demonstrated in mice, in the absence of immune responses, transposition is a critical factor that affects the longevity of expression. ${ }^{13}$ Excision products that are the prime evidence of transposition were detected in liver samples from a normal dog infused with $h G U S B$ transposon, which was co-administered with pCMVSB100X plasmid. In contrast, in dogs infused with hIDUA-encoding transposon with the 10- to 20fold weaker SB11 transposase ${ }^{13}$ excision products were not detected, even though the IDUA transposons and transposase $S B 11$ were on the same plasmid. Apparently, to achieve detectable transposition of therapeutic SB transposons into canine hepatocyte genomes, the strongest SB transposase, SB100X, must be used. Inclusion of the SB transposon and transposase expression cassettes on the same plasmid assures that both components of the transposon system are present in successfully transfected cells. While cis and trans SB delivery yielded comparable transposition frequencies in mice, the cis configuration may be preferable for treating dogs because delivery is roughly 100 -fold lower. More work on this aspect of transposon delivery is needed.

Previously, the kinetics of loss underlying SBmediated hIDUA expression were analyzed in mice treated using many different conditions, such as ubiquitous CAGGS versus liver-specific ApoEhCRhAAT promoter, SB11 versus SB100X transposase, cis versus trans $\mathrm{SB}$ transposon configuration, different DNA doses, timmunosuppression, and so on. ${ }^{13}$ It was found that many combinations of factors affecting transgene expression lead to only a limited number of post-treatment scenarios. Without immunosuppression, in mice, expression was lost rapidly, independently of transposition (e.g., half-life of hIDUA was 1-2 days). This is similar to what was observed in dogs in the absence of immunosuppression. However, when mice were immune suppressed, stable expression was attained due to transposition, and stabilized expression from episomes at levels deemed therapeutic for MPS I was never observed. Nevertheless, episomal expression in immunesuppressed mice could continue for months. ${ }^{13}$ This explains prolonged declining expression in cSEAPtreated dogs, which is predominantly episomal.

In viral and non-viral liver-directed gene therapy for systemic disease, such as hemophilia or MPS I and VII, the levels of sustained therapeutic protein secreted from the liver into the blood determine the extent of correction. ${ }^{19,61-63}$ Hemophilia A and B correction requires a relatively low continuous presence of normal protein in the circulation. Thus, Cantore et $a l .{ }^{64}$ showed that liver-directed lentiviral vectormediated gene therapy of canine hemophilia B dogs provided stable, long-term FIX activity up to $1 \%$ of normal with therapeutic benefit. Moreover, in a human clinical trial, Nathwani et al. achieved stable therapeutic expression of FIX at around 5\% of the normal level lasting $>4$ years after a single i.v. administration of an adeno-associated virus vector encoding FIX. ${ }^{65}$ Higher transgene expression will be required for MPS. Bigg et al. ${ }^{33}$ monitored animals after i.v. injection of gamma-retroviral vector into neonatal MPS VII dogs for 11 years and reported that sustained serum GUSB at $41 \%$ of WT had beneficial effects on heart valves and prolonged life-span. Thus, stable activity at about $40 \%$ WT levels represents a reasonable target for treatment of human patients with MPS I and MPS VII, which is also comparable to the amount of enzyme delivered by enzyme replacement therapy. Moreover, mouse studies in MPS IIIA indicate the superiority of continual slow infusion versus repeated bolus injection of the recombinant enzyme in ameliorating MPS IIIA. ${ }^{66}$

This study is a proof of principle that immune suppression can improve maintenance of the active transgenic protein in serum. Potent immune suppression strategies are currently being explored for translation of preclinical studies to large animal models and humans that also permit re-dosing in such common scenarios as liver growth, vector silencing, and loss of transduced liver cells. ${ }^{35,67-70}$ In future studies, it will be important to determine which types of immune response cause the decline in transgene expression in order to find effective immune suppressive therapy. However, hepatic delivery remains the Achilles heel in non-viral gene therapy studies aiming at clinical trials. ${ }^{42-44}$ It remains to be seen whether the SB transposons can be used in the in vivo approach as successfully as they are being used to treat blood cancers in human patients. ${ }^{71}$

\section{ACKNOWLEDGMENTS}

We thank our colleagues on the Program Project Grant for Gene Therapy for Metabolic Disorders and members of the Center for Genome Engineering for advice and critiques, Dr. Kathy Ponder for the gift of canine GUSB cDNA, and Dr. Mark Kay for pAAV-hFIX16 plasmid containing the liverspecific promoter. Breeding stock for the MPS VII dog in this study was derived from a colony supported by the NIH grant NS085381 to Patricia I. Dickson. This work was supported by $\mathrm{NIH}$ grants R01DK082516 and P0HD32652 to the University of Minnesota and R44HL072539 and R41DK081249 to Discovery Genomics, Inc. 


\section{AUTHOR DISCLOSURE}

P.B.H., K.A.H., E.R.O., and R.S.M. have equity in Immusoft, Inc. E.R.O. and R.S.M. are employees of Immusoft, Inc. (formerly Discovery Genomics, Inc.). E.L.A, B.C.H, J.B.B, M.U.R., D.W.H., and N.M.E. have no competing financial interests.

\section{REFERENCES}

1. Hackett PB, Largaespada DA, Switzer KC, et al. Evaluating risks of insertional mutagenesis by DNA transposons in gene therapy. Transl Res 2013;161:265-283.

2. Hackett PB, Starr TK, Cooper LC. Risks of insertional mutagenesis by DNA transposons in cancer gene therapy. In: Translating Gene Therapy to the Clinic: Techniques and Approaches. Amsterdam, The Netherlands: Elsevier Inc., 2015:65-83.

3. Singh H, Huls H, Kebriaei P, et al. A new approach to gene therapy using Sleeping Beauty to genetically modify clinical-grade T cells to target CD19. Immunol Rev 2014;257:181-190.

4. Hackett PB Jr, Aronovich EL, Hunter D, et al. Efficacy and safety of Sleeping Beauty transposonmediated gene transfer in preclinical animal studies. Curr Gene Ther 2011;11:341-349.

5. Zhang G, Budker V, Wolff JA. High levels of foreign gene expression in hepatocytes after tail vein injections of naked plasmid DNA. Hum Gene Ther 1999;10:1735-1737.

6. Liu F, Song Y, Liu D. Hydrodynamics-based transfection in animals by systemic administration of plasmid DNA. Gene Ther 1999;6:12581266

7. Ivics Z, Hackett PB, Plasterk RH, et al. Molecular reconstruction of Sleeping Beauty, a Tc1-like transposon from fish, and its transposition in human cells. Cell 1997;91:501-510.

8. Ivics Z, Izsvák Z. Sleeping Beauty transposition. Microbiol Spectr 2015;3:MDNA3-0042-2014.

9. Izsvák Z, Hackett PB, Cooper LJ, et al. Translating Sleeping Beauty transposition into cellular therapies: victories and challenges. Bioessays 2010; 32:756-767.

10. Hackett PB, Largaespada DA, Cooper LJ. A transposon and transposase system for human application. Mol Ther 2010;18:674-683.

11. Yant SR, Meuse L, Chiu W, et al. Somatic integration and long-term transgene expression in normal and haemophilic mice using a DNA transposon system. Nat Genet 2000;25:35-41.

12. Aronovich EL, Mclvor RS, Hackett PB. The Sleeping Beauty transposon system: a non-viral vector for gene therapy. Hum Mol Genet 2011;20:14-20.

13. Aronovich EL, Hall BC, Bell JB, et al. Quantitative analysis of $\alpha$-L-Iduronidase expression in immunocompetent mice treated with the Sleeping Beauty transposon system. PLoS One 2013;8: e78161.

14. Geurts AM, Hackett CS, Bell JB, et al. Structurebased prediction of insertion-site preferences of transposons into chromosomes. Nucleic Acids Res 2006;34:2803-2811

15. Ohlfest JR, Frandsen JL, Fritz S, et al. Phenotypic correction and long-term expression of factor VIII in hemophilic mice by immunotolerization and nonviral gene transfer using the Sleeping Beauty transposon system. Blood 2005;105:2691-2698.

16. Mikkelsen JG, Yant SR, Meuse L, et al. HelperIndependent Sleeping Beauty transposon-transposase vectors for efficient nonviral gene delivery and persistent gene expression in vivo. Mol Ther 2003; 8:654-665.

17. Hausl MA, Zhang W, Müther N, et al. Hyperactive Sleeping Beauty transposase enables persistent phenotypic correction in mice and a canine model for hemophilia B. Mol Ther 2010;18:1896-1906.

18. Aronovich EL, Bell JB, Belur LR, et al. Prolonged expression of a lysosomal enzyme in mouse liver after Sleeping Beauty transposon-mediated gene delivery: implications for non-viral gene therapy of mucopolysaccharidoses. J Gene Med 2007:9:403-415.

19. Aronovich EL, Bell JB, Khan SA, et al. Systemic correction of storage disease in MPS I NOD/SCID mice using the Sleeping Beauty transposon system. Mol Ther 2009;17:1136-1144.

20. Ponder KP. Hemophilia gene therapy: a Holy Grail found. Mol Ther 2011;19:427-428.

21. Lheriteau E, Davidoff AM, Nathwani AC. Haemophilia gene therapy: progress and challenges. Blood Rev 2015;29:321-328.

22. Wraith JE, Jones $S$. Mucopolysaccharidosis type I. Pediatr Endocrinol Rev 2014;12:102-106.

23. Sands MS. Mucopolysaccharidosis type VII: a powerful experimental system and therapeutic challenge. Pediatr Endocrinol Rev 2014;12:159-165.

24. Ponder KP, Haskins ME. Gene therapy for mucopolysaccharidosis. Expert Opin Biol Ther 2007; 7:1333-1345

25. Shull RM, Munger RJ, Spellacy E, et al. Canine alpha-L-iduronidase deficiency. A model of mucopolysaccharidosis I. Am J Pathol 1982;109:244248.

26. Menon KP, Tieu PT, Neufeld EF. Architecture of the canine IDUA gene and mutation underlying canine mucopolysaccharidosis I. Genomics 1992; 14:763-768.

27. Haskins ME, Desnick RJ, DiFerrante N, et al. Betaglucuronidase deficiency in a dog: a model of human mucopolysaccharidosis VII. Pediatr Res 1984;18:980-984.

28. Ray J, Haskins ME, Ray K. Molecular diagnostic tests for ascertainment of genotype at the mu- copolysaccharidosis type VII locus in dogs. Am J Vet Res 1998:59:1092-1095

29. Mango RL, Xu L, Sands MS, et al. Neonatal retroviral vector-mediated hepatic gene therapy reduces bone, joint, and cartilage disease in mucopolysaccharidosis VII mice and dogs. Mol Genet Metab 2004;82:4-19.

30. Traas AM, Wang P, Ma X, et al. Correction of clinical manifestations of canine mucopolysaccharidosis I with neonatal retroviral vector gene therapy. Mol Ther 2007;33:1423-1431.

31. Herati RS, Knox VW, O'Donnell P, et al. Radiographic evaluation of bones and joints in mucopolysaccharidosis I and VII dogs after neonatal gene therapy. Mol Genet Metab 2008;95:142151.

32. Metcalf JA, Linders B, Wu S, et al. Upregulation of elastase activity in aorta in mucopolysaccharidosis I and VII dogs may be due to increased cytokine expression. Mol Genet Metab 2010;99: 396-407.

33. Bigg PW, Sleeper MM, O'Donnell PA, et al. The effect of neonatal gene therapy with a gamma retroviral vector on cardiac valve disease in mucopolysaccharidosis VII dogs after a decade. Mol Genet Metab 2013;110:311-318.

34. Gurda BL, De Guilhem De Lataillade A, Bell P, et al. Evaluation of AAV-mediated gene therapy for central nervous system disease in canine mucopolysaccharidosis VII. Mol Ther 2015;24: 206-216.

35. Hinderer C, Bell P, Louboutin JP, et al. Neonatal systemic AAV induces tolerance to CNS gene therapy in MPS I dogs and nonhuman primates. Mol Ther 2015;23:1298-1307.

36. Bradbury AM, Gurda BL, Casal ML, et al. A review of gene therapy in canine and feline models of lysosomal storage disorders. Hum Gene Ther Clin Dev 2015;26:27-37.

37. Ma $X$, Liu $Y$, Tittiger $M$, et al. Improvements in mucopolysaccharidosis I mice after adult retroviral vector-mediated gene therapy with immunomodulation. Mol Ther 2007;15:889902.

38. Arruda VR, Favaro P, Finn JD. Strategies to modulate immune responses: a new frontier for gene therapy. Mol Ther 2009;17:1492-1503.

39. Ye P, Thompson AR, Sarkar R, et al. Naked DNA transfer of Factor VIII induced transgene-specific, species-independent immune response in hemophilia A mice. Mol Ther 2004;10:117-126.

40. Manno CS, Pierce GF, Arruda VR, et al. Successful transduction of liver in hemophilia by AAV-Factor 
IX and limitations imposed by the host immune response. Nat Med 2006;12:342-347.

41. Hyland KA, Aronovich EL, Olson ER, et al. Transgene expression in dogs after liver-directed hydrodynamic delivery of Sleeping Beauty transposons using balloon catheters. Hum Gene Ther 2017;28:541-550.

42. Suda T, Liu D. Hydrodynamic delivery. Adv Genet 2015;89:89-111.

43. Sendra L, Pérez D, Miguel A, et al. Human AAT gene transfer to pig liver improved by using a perfusion isolated organ endovascular procedure. Eur Radiol 2016;26:95-102.

44. Stoller F, Schlegel A, Viecelli HM, et al. Hepatocyte transfection in small pigs after weaning by hydrodynamic intraportal injection of naked DNA/ minicircle vectors. Hum Gene Ther Methods 2015;26:181-192.

45. Cui Z, Geurts AM, Liu G, et al. Structure-function analysis of the inverted terminal repeats of the Sleeping Beauty transposon. J Mol Biol 2002; 318:1221-1235.

46. Geurts AM, Yang Y, Clark KJ, et al. Gene transfer into genomes of human cells by the Sleeping Beauty transposon system. Mol Ther 2003;8:108-117.

47. Mátés L, Chuah MK, Belay E, et al. (2009). Molecular evolution of a novel hyperactive Sleeping Beauty transposase enables robust stable gene transfer in vertebrates. Nat Genet 2009;41:753-761.

48. Wolf DA, Hanson LR, Aronovich EL, et al. Lysosomal enzyme can bypass the blood-brain barrier and reach the CNS following intranasal administration. Mol Genet Metab 2012;106:131-134

49. Wolfe JH, Sands MS. Murine mucopolysaccharidosis type VII: a model system for somatic gene therapy for the central nervous system. In: Lowenstein PR, Enquist LW, eds. Protocols for Gene Transfer in Neuroscience: Towards Gene Therapy of Neurological Disorders. Chichester, United Kingdom: John Wiley and Sons, 1996:263-274.

50. Podetz-Pedersen KM, Olson ER, Somia NV, et al. A broad range of dose optima achieve high-level, long-term gene expression after hydrodynamic delivery of Sleeping Beauty transposons using hyperactive SB100X Transposase. Mol Ther Nucleic Acids 2016;5:e279.
51. Giannini EG, Testa R, Savarino V. Liver enzyme alteration: a guide for clinicians. CMAJ 2005;172: 367-379.

52. Botros M, Sikaris KA. The De Ritis Ratio: the test of time. Clin Biochem Rev 2013;34:117-30.

53. Yokoo T, Kamimura K, Suda T, et al. Novel electric power-driven hydrodynamic injection system for gene delivery: safety and efficacy of human factor IX delivery in rats. Gene Ther 2013;20:816-823.

54. Kolios G, Valatas V, Kouroumalis E. Role of Kupffer cells in the pathogenesis of liver disease. World J Gastroenterol 2006;12:7413-7420.

55. Hardonk MJ, Dijkhuis FW, Hulstaert CE, et al. Heterogeneity of rat liver and spleen macrophages in gadolinium chloride-induced elimination and repopulation. J Leukoc Biol 1992:52:296-302.

56. Podetz-Pedersen KM, Vezys V, Somia NV, et al. Cellular immune response against firefly luciferase after Sleeping Beauty-mediated gene transfer in vivo. Hum Gene Ther 2014;25:955-965.

57. Neufeld EF, Muenzer J. The mucopolysaccharidoses. In: Scriver CR, Beaudet AL, Sly WS, et al., eds. The Metabolic and Molecular Bases of Inherited Disease. Vol. III. 8th ed. New York: McGraw-Hill, 2001:3427-3436.

58. Whitley CB, Belani KG, Chang PN, et al. Long-term outcome of Hurler syndrome following bone marrow transplantation. Am J Med Genet 1993; 46:209-218.

59. Guffon N, Souillet G, Maire I, et al. Follow-up of nine patients with Hurler syndrome after bone marrow transplantation. J Pediatr 1998;133:119 125.

60. Bell JB, Aronovich EL, Schreifels JM, et al. Duration of expression and activity of Sleeping Beauty transposase in mouse liver following hydrodynamic DNA delivery. Mol Ther 2010;18: 1796-1802.

61. Xu L, Mango RL, Sands MS, et al. Evaluation of pathological manifestations of disease in mucopolysaccharidosis VII mice after neonatal hepatic gene therapy. Mol Ther 2002;6:745-758.

62. Cotugno G, Tessitore A, Capalbo A, et al. Different serum enzyme levels are required to rescue the various systemic features of the mucopolysaccharidoses. Hum Gene Ther 2010;21:555-569.
63. Baldo G, Wozniak DF, Ohlemiller KK, et al Retroviral-vector-mediated gene therapy to mucopolysaccharidosis I mice improves sensorimotor impairments and other behavioral deficits. J Inherit Metab Dis 2013:36:499-512.

64. Cantore A, Ranzani M, Bartholomae CC, et al Liver-directed lentiviral gene therapy in a dog model of hemophilia B. Sci Transl Med 2015;7: 277ra28.

65. Nathwani AC, Reiss UM, Tuddenham EG, et al. Long-term safety and efficacy of factor IX gene therapy in hemophilia B. N Engl J Med 2014;371: 1994-2004

66. Beard H, Hassiotis S, Luck AJ, et al. Continual low-dose infusion of sulfamidase is superior to intermittent high-dose delivery in ameliorating neuropathology in the MPS IIIA mouse brain. JIMD Reports 2015;29:59-68.

67. Sack BK, Herzog RW, Terhorst C, et al. Development of gene transfer for induction of antigenspecific tolerance. Mol Ther Methods Clin Dev 2014;1:14013.

68. Corti M, Cleaver B, Clément N, et al. Evaluation of readministration of a recombinant adenoassociated virus vector expressing acid alphaglucosidase in Pompe disease: preclinical to clinical planning. Hum Gene Ther Clin Dev 2015; 26:185-193.

69. Han SO, Li S, Brooks ED, et al. Enhanced efficacy from gene therapy in Pompe disease using coreceptor blockade. Hum Gene Ther 2015;26:26-35.

70. Naldini L. Gene therapy returns to centre stage Nature 2015;526:351-360

71. Kebriae $P$, Singh $H$, Huls $M H$, et al. Phase I trials using Sleeping Beauty to generate CD19-specific T cells. J Clin Invest 2016;126:3363-3376.

72. Herzog RW, Arruda VR, Fisher TH, et al. Absence of circulating factor IX antigen in hemophilia $B$ dogs of the UNC-Chapel Hill colony. Thromb Haemost 2000;84:352-354.

Received for publication January 4, 2017 ; accepted after revision May 16, 2017.

Published online: May 19, 2017. 